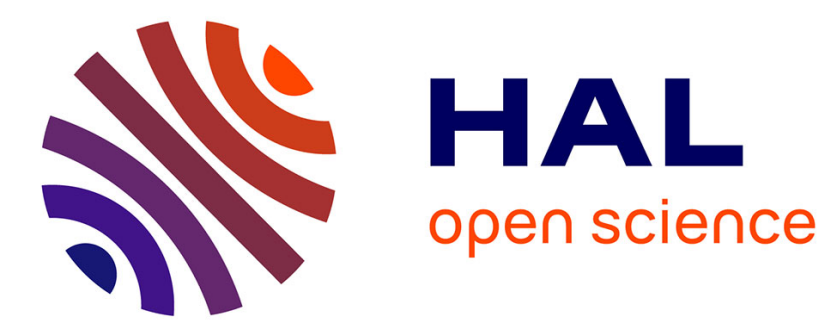

\title{
Effect of the inclusion of adsorbents on aflatoxin B1 quantification in animal feedstuffs
}

Antonio Gallo, Francesco Masoero, Terenzio Bertuzzi, Gianfranco Piva, Amedeo Pietri

\section{- To cite this version:}

Antonio Gallo, Francesco Masoero, Terenzio Bertuzzi, Gianfranco Piva, Amedeo Pietri. Effect of the inclusion of adsorbents on aflatoxin B1 quantification in animal feedstuffs. Food Additives and Contaminants, 2009, 27 (01), pp.54-63. 10.1080/02652030903207219 . hal-00573908

\section{HAL Id: hal-00573908 \\ https://hal.science/hal-00573908}

Submitted on 5 Mar 2011

HAL is a multi-disciplinary open access archive for the deposit and dissemination of scientific research documents, whether they are published or not. The documents may come from teaching and research institutions in France or abroad, or from public or private research centers.
L'archive ouverte pluridisciplinaire HAL, est destinée au dépôt et à la diffusion de documents scientifiques de niveau recherche, publiés ou non, émanant des établissements d'enseignement et de recherche français ou étrangers, des laboratoires publics ou privés. 


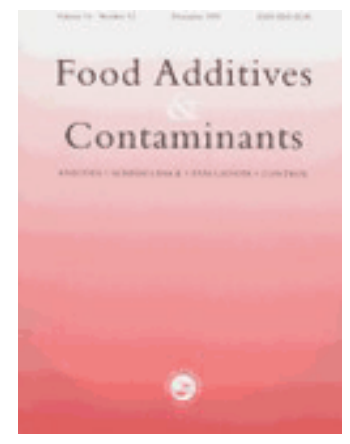

\section{Effect of the inclusion of adsorbents on aflatoxin $B_{1}$ quantification in animal feedstuffs}

\begin{tabular}{|r|l|}
\hline Journal: & Food Additives and Contaminants \\
\hline Manuscript ID: & TFAC-2009-070.R1 \\
\hline Manuscript Type: & Original Research Paper \\
\hline Author: & 15-Jul-2009 \\
\hline Complete List of Authors: & $\begin{array}{l}\text { Gallo, Antonio; Università Cattolica del Sacro Cuore, Istituto di } \\
\text { Scienze degli Alimenti e della Nutrizione } \\
\text { Masoero, Francesco; Università Cattolica del Sacro Cuore, Istituto di } \\
\text { Scienze degli Alimenti e della Nutrizione } \\
\text { Bertuzzi, Terenzio; Istituto di Scienze degli Alimenti e della } \\
\text { Nutrizione } \\
\text { Piva, Gianfranco; Università Cattolica del Sacro Cuore, Istituto di } \\
\text { Scienze degli Alimenti e della Nutrizione } \\
\text { Pietri, Amedeo; Università Cattolica del Sacro Cuore, Istituto di } \\
\text { Scienze degli Alimenti e della Nutrizione }\end{array}$ \\
\hline Methods/Techniques: & Chromatography - HPLC, Extraction \\
\hline Additives/Contaminants: & Aflatoxins \\
\hline Food Types: & Animal feedingstuffs, Milk \\
\hline & \\
\hline
\end{tabular}

\section{SCHOLARONE Manuscripts}


4 Effect of the inclusion of adsorbents on aflatoxin $B_{1}$ quantification in animal feedstuffs

6 A. Gallo*, F. Masoero, T. Bertuzzi, G. Piva, \& A. Pietri

7 Istituto di Scienze degli Alimenti e della Nutrizione, Facoltà di Agraria, Università Cattolica del Sacro 8 Cuore, Via Emilia Parmense 84, 29100 Piacenza, Italy

\section{Abstract}

11 The extraction efficiency of aflatoxin $\mathrm{B}_{1}\left(\mathrm{AFB}_{1}\right)$ in cattle feed containing 9 adsorbents (ADSs), was 12 investigated using two organic/aqueous solvents, composed of methanol/water (80/20 v/v; $\mathrm{MeOH})$ and 13 acetone/water $(85 / 15 \mathrm{v} / \mathrm{v} ; \mathrm{AC})$. Samples were obtained including a highly $\mathrm{AFB}_{1}$ contaminated (HC) 14 and a low level $\mathrm{AFB}_{1}$ contaminated (LC) feedstuffs (15.33 and $7.57 \mu \mathrm{g} \mathrm{kg}^{-1}$, respectively), nine ADSs 15 (4 clay minerals; 1 yeast cell wall-based product; 1 activated carbon and 3 commercial ADS products) 16 at two different levels of inclusion (10 and $\left.20 \mathrm{~g} \mathrm{~kg}^{-1}\right)$. After solvent extraction and immunoaffinity 17 column clean-up, all samples were analysed for $\mathrm{AFB}_{1}$ by HPLC with fluorescence detection. For each 18 contamination level ( $\mathrm{HC}$ and $\mathrm{LC}$ ), the data obtained were analysed using a factorial arrangement in a completely randomized design. Means were compared to the correspondent controls using the Dunnett's test. No statistical difference was found in $\mathrm{AFB}_{1}$ levels of feedstuffs not containing ADSs, when extracted with $\mathrm{AC}$ or $\mathrm{MeOH}$, even if numerically higher values were obtained with AC. A dosedependent effect $(P<0.01)$ of ADSs inclusion was observed on $\mathrm{AFB}_{1}$ recoveries, that were lower when the higher ADS level $\left(20 \mathrm{~g} \mathrm{~kg}^{-1}\right)$ was included in the $\mathrm{HC}$ and LC feedstuffs. Higher $\mathrm{AFB}_{1}$ recoveries were obtained using $\mathrm{AC}$ compared to $\mathrm{MeOH}$, both in $\mathrm{HC}$ (75.0 vs. 12.0\%, respectively) and in LC (84.0 vs. 22.8\%, respectively) ADSs containing feedstuffs. However, when activated carbon and the sodium bentonite were included in feeds, lower $\mathrm{AFB}_{1}$ concentrations with respect to control values

\footnotetext{
*Corresponding author. Email: antonio.gallo@unicatt.it
} 
27 ( $\mathrm{P}<0.001$ and $\mathrm{P}<0.05$, respectively) were obtained also using AC. The data obtained in this study 28 indicate that routine use of the $\mathrm{MeOH}$ solvent for $\mathrm{AFB}_{1}$ analysis of unknown feedstuffs, can produce 29 misleading results if they contain an ADS.

30 Keywords: aflatoxin $\mathrm{B}_{1}$, analysis, feedstuffs, adsorbents, solvents

\section{Introduction}

Crops such as corn, cotton and peanuts and their industrial by-products are frequently contaminated by aflatoxins (AFs), hepatocarcinogenic molecules (IARC, 2002) produced primarily by Aspergillus flavus and A. parasiticus, either in field or during transport or storage (Scheidegger and Payne, 2003).

Aflatoxin $\mathrm{B}_{1}\left(\mathrm{AFB}_{1}\right)$, the most toxic and carcinogenic aflatoxins (AFs) (Roebuck and Maxuitenko, 1994), once ingested by mammals is absorbed in the gastro-intestinal tract and appears rapidly in blood (Gallo et al., 2008) and in milk (Veldman et al., 1992a; Masoero et al., 2007) as aflatoxin $\mathrm{M}_{1}\left(\mathrm{AFM}_{1}\right)$, the principal $\mathrm{AFB}_{1}$ hydroxylated metabolite. The $\mathrm{AFB}_{1}$ carry over $(\mathrm{CO})$ rate into milk as $\mathrm{AFM}$ has been determined to range from $1 \%$ to $3 \%$ in lactating dairy cows and to be principally affected by milk yield (Diaz et al., 2004; Van Eijkeren et al., 2006; Masoero et al., 2007), with a reported maximum value of about $6 \%$ (Veldman et al., 1992a).

The limits for $\mathrm{AFB}_{1}$ fixed by the European Commision (EC) in animal feeds and complete feedingstuffs for dairy animals are 20 and $5 \mu \mathrm{g} \mathrm{kg}^{-1}$, respectively (European Commission, 2003). In milk, the EC set the $\mathrm{AFM}_{1}$ maximum permitted level at $0.050 \mu \mathrm{g} \mathrm{kg}^{-1}$ (European Commission, 2006), while in the USA the maximum $\mathrm{AFM}_{1}$ concentration is regulated by the Food and Drug Administration (FDA) at $0.500 \mu \mathrm{g} \mathrm{kg}^{-1}$ (Berg, 2003).

Various equations to predict the $\mathrm{AFM}_{1}$ level in milk (ng kg${ }^{-1}$ ) from $\mathrm{AFB}_{1}$ intake $(\mu \mathrm{g}$ per cow per day) have been proposed (Veldman et al., 1992a; Pettersson et al., 1989; Van Eijkeren et al., 2006). In dairy farms, the precise $\mathrm{AFB}_{1}$ determination in animal feeds is useful to predict the $\mathrm{AFM}_{1}$ concentration in milk and to avoid contamination levels exceeding the legal limits. 
The analytical methods for $\mathrm{AFB}_{1}$ detection/quantification in foods and feedstuffs are based on

different separation/detection techniques (Trucksess and Wood, 1994; Stroka et al., 1999), such as enzyme linked immunosorbent assay (ELISA) (Aldao et al., 1995), HPLC (Sharma and Marquez, 2001; Stroka et al., 2003; Arranz et al., 2006) or TLC (Bradburn et al., 1995). All these techniques need an efficient sample extraction method. Several studies have been conducted to investigate the extraction capacity of different organic/aqueous solvents, like methanol (Reif and Metzger, 1995; Stroka et al., 1999; Sharma and Marquez, 2001; Senyuva and Gilbert, 2005; Brera et al., 2007), acetone (Brandurn et al., 1995; Stroka et al., 2003; Arranz et al., 2006), acetonitrile (Stroka et al., 1999) and chloroform (Moller and Nyberg, 2004) solvents. Some studies investigated the organic solvent to water ratio $(\mathrm{ml}$ solvent $/ \mathrm{ml}$ water), the ratio of solvent to sample ( $\mathrm{ml}$ solvent/g sample) and the matrix effects (Brandburn et al., 1995; Stroka et al., 1999; Moller and Nyberg, 2004).

The $\mathrm{AFB}_{1}$ method based on a methanol:water $(80: 20 \mathrm{v} / \mathrm{v})$ extraction procedure $(\mathrm{MeOH})$ and on HPLC determination after an immunoaffinity clean-up step, seems to be the most common method in AFs-specialized laboratories (Trucksess and Wong, 1994; Stroka et al., 1999; Sharma and Màrquez, 2001; Moller and Nyberg, 2004). However, the method based on an acetone:water (85:15 v/v) solvent (AC) to extract AFs from feeds is also used in many laboratories, being the AOAC reference method (2003.2) for $\mathrm{AFB}_{1}$ analysis (Stroka et al., 2003; AOAC, 2006).

One of the most recent approaches to the prevention of mycotoxicoses in livestock is the addition of adsorbents (ADSs) in the diet, that bind mycotoxins in the gastro-intestinal tract and are capable of reducing their bioavailability (Jouany et al., 2007; Masoero et al., 2009). Certain ADSs can decrease the aflatoxin CO in milk of dairy animals (Diaz and Smith, 2005; Jouany; 2007). Mycotoxin binders belong to three different groups: silicate materials or clay minerals (Phillips et al., 1991; Ramos and Hernandez, 1996), yeast cell wall-based products (Karaman et al., 2005; Yiannikouris et al., 2005), and activated charcoals (Galvano et al., 1996). However, these additives are not at present authorized in 
75 Europe for this purpose and they are currently added to industrial feeds as ingredients (yeast cell wall76 based products) or anti-caking agents to improve feed pelleting efficiency (clay minerals) (Jaynes et al., 77 2007).

78 No specific work has been published regarding the AF extraction efficiency of solvents (acetone and 79 methanol mixed with different percentages of water) in animal feedstuffs containing mycotoxin ADSs, 80 even if some authors (Veldman, 1992b; Galvano et al., 1996) indicated that the presence of clay ADSs 81 in feeds could reduce the analytical recovery of $\mathrm{AFB}_{1}$.

82 The aim of this study was to examine if the inclusion of sequestering agents in $\mathrm{AFB}_{1}$ contaminated 83 feedstuffs can affect the extraction capacity of $\mathrm{AC}$ or $\mathrm{MeOH}$ extracting solvents.

\section{Materials and methods}

\section{$86 \quad$ Preparation of feeds}

87 Two $\mathrm{AFB}_{1}$ contaminated complete feedstuffs (1350 kg each) were produced in an industrial feed 88 mill, using $\mathrm{AFB}_{1}$ naturally contaminated ingredients: two corn meals $(10.21 \pm 1.27$ and $32.87 \pm 2.32 \mu \mathrm{g}$ $\left.89 \mathrm{~kg}^{-1}\right)$, wheat bran $\left(1.40 \pm 0.31 \mu \mathrm{g} \mathrm{kg}^{-1}\right)$, and soybean meal $\left(1.11 \pm 0.23 \mu \mathrm{g} \mathrm{kg}^{-1}\right)$; the other ingredients 90 were uncontaminated barley and sunflower meal, and a mineral/vitamin supplement. The two maize 91 meals were used in order to obtain, respectively, a low contaminated (LC; $7.57 \pm 0.65 \mu \mathrm{g} \mathrm{kg}{ }^{-1}$ ) 92 feedstuff with a contamination close to the EC limit of $5 \mu \mathrm{g} \mathrm{kg}^{-1}$ (European Commission, 2003) and a 93 highly contaminated $\left(\mathrm{HC} ; 15.33 \pm 1.12 \mu \mathrm{g} \mathrm{kg}^{-1}\right)$ feedstuff with a contamination three times higher than 94 the EU limit (Table 1). Both feeds, free of clay minerals or other anti-caking agents, were mixed for 4 95 minutes in a $2000 \mathrm{~kg}$ industrial mixer (MO/20, Grespan, Treviso, Italy).

96 The two contaminated feeds were divided into 108 sub-samples ( $25 \mathrm{~kg}$ each), 54 for LC and 54 for $97 \mathrm{HC}$, and tested for the $\mathrm{AFB}_{1}$ contamination homogeneity, randomly selecting and checking 9 samples 98 for LC and 9 samples for HC. The 18 samples were analyzed in duplicate with $\mathrm{AC}$ and $\mathrm{MeOH}$ 
extraction solvents (Table 1).

In this study we tested four different types of silicate minerals (sodium and calcium bentonite clays; zeolite and kaolinite), one yeast cell wall-based product, an activated carbon, and three commercial products commonly used in industrial feed mills and in dairy farms (Table 2) (Masoero et al., 2009).

The ADSs were characterized for elementary composition (Table 2) and used at two inclusion levels (10 and $20 \mathrm{~g} \mathrm{~kg}^{-1}$ ) in LC and HC feedstuffs. The nine ADSs were a sodium bentonite (Amcol International Corp., Arlington Heights, IL, USA), a calcium bentonite (Tecnozoo, Padova, Italy), a zeolite (Fluka 96096, Sigma-Aldrich Chemie Gmbh, Switzerland), a kaolinite (Fluka 03584, SigmaAldrich Chemie Gmbh, Switzerland); a yeast cell wall-based product (Mycosorb ${ }^{\circledR}$, Alltech Italy, Bologna, Italy), an activated carbon product (Acque Nymco, Milan, Italy), and three commercial ADSs (Atox $^{\circledR}$, Grupo Tolsa, Madrid, Spain; Myco AD AZ, Ascor Chimici, Forlì-Cesena, Italy; Novasil ${ }^{\mathrm{TM}}$ plus, Trouw Nutrition Int., Verona, Italy). The manufacturer's specifications of the commercial products classify Atox ${ }^{\circledR}$ and Myco AD AZ as clay mixtures where the presence of aluminosilicates of the smectite group exceeds $85 \%$ of the product. In particular, the first could be considered a magnesium bentonite, being magnesium the dominant cation, while the second is a mixture of sodium and calcium bentonite. Novasil ${ }^{\mathrm{TM}}$ plus is generally described by the producer as a hydrated sodium calcium aluminosilicate. Recently, some authors reported that this product could be classified as a montmorillonite clay (Pimpukdee et al., 2004, Bailey et al., 2006).

The 108 feed sub-samples were randomly assigned to the 9 ADSs (12 sub-samples each) to obtain 3 replicates for the two inclusion levels $\left(10\right.$ and $20 \mathrm{~g} \mathrm{~kg}^{-1}$ ) and the two contamination levels (LC and $\mathrm{HC}$ ). Then, all the sub-samples were mixed for 4 minutes in a $50 \mathrm{~kg}$ mixer before being analyzed for the $\mathrm{AFB}_{1}$ content.

The experimental model studied the effects of: contamination levels (LC and HC); ADSs ( $n=9)$; doses $\left(10\right.$ and $\left.20 \mathrm{~g} \mathrm{~kg}^{-1}\right)$ and replicates $(\mathrm{n}=3)$ for a total of 108 samples. 


\section{Chemicals}

125 Solvents and reagents. Solvents used were of grade ACS-ISO. Acetonitrile, acetone and methanol were

\section{Extraction procedures}

Sample preparation and clean up. To determine $\mathrm{AFB}_{1}$ in feeds, $25 \mathrm{~g}$ of sample were extracted with 250 $\mathrm{ml}$ of a methanol/water mixture (MeOH, 80:20, v/v) according to Stroka et al. (1999), or with $250 \mathrm{ml}$ of an acetone/water mixture (AC, 85:15 v/v) according to AOAC method 2003.2 (AOAC, 2006); samples were shaken using a rotary shaker for $45 \mathrm{~min}$ and filtered through a Schleicher \& Schuell 595 
1/2 filter paper (Dassel, Germany). Five $\mathrm{ml}$ of the filtrate were diluted with $45 \mathrm{ml}$ of distilled water and the solution was purified through an immunoaffinity column (R-Biopharm Rhône Ltd, Glasgow, UK), previously conditioned with $20 \mathrm{ml}$ of PBS. After washing, the column with $5 \mathrm{ml}$ distilled water, $\mathrm{AFB}_{1}$ was slowly eluted with $2.5 \mathrm{ml}$ of methanol.

The eluate was dried under a gentle stream of nitrogen, re-dissolved in $1 \mathrm{ml}$ of acetonitrile:water $(25: 75, v / v)$, and vortex-mixed for a few seconds; the extract was then filtered (Millipore Corporation, Bedford, Massachusetts, USA; HV $0.45 \mu \mathrm{m})$ and injected (30 $\mu \mathrm{l})$ into the HPLC.

\section{Apparatus}

Analysis was performed using an HPLC instrument consisting of a LC-200 pump (Perkin Elmer, Norwalk, CT, USA) an AS-2055 sampling system, a FP-1520 fluorescence detector (Jasco Corporation, Tokyo, Japan), and a UV derivatizer (UVE ${ }^{\mathrm{TM}}$ derivatizer, LC tech, Dorfen, Germany); the instrument was controlled by Borwin 1.5 software (Jasco). A Superspher RP-18 column (4 $\mu$ m particle size, 125 x 4 mm i.d., Merck) was used at ambient temperature with a mobile phase of water:methanol:acetonitrile $(64: 23: 13, \mathrm{v} / \mathrm{v} / \mathrm{v})$ at $1 \mathrm{ml} \mathrm{min}^{-1}$. The $\mathrm{AFB}_{1}$ was detected after post-column photochemical derivatization to $\mathrm{AFB}_{2 \alpha}$. The detector was set at $365 \mathrm{~nm}$ excitation and $440 \mathrm{~nm}$ emission wavelengths.

The elemental components of the ADSs were determined by a semi-quantitative X-ray fluorescence analysis (Sànchez-Ramos et al., 2008) using the scanning electron microscope Phillips XL 30 E-SEM (Phillips electron Optics B.V., Eindhoven, Netherlands) equipped with an energy-dispersive X-ray detector model Genesis (Edax Inc., Mc Kee Drive, Mahwah NY, USA) operating in low vacuum.

\section{Recovery experiment}

Before analysis of feeds, the $\mathrm{AFB}_{1}$ recoveries were performed with an AF-free cattle feed $\left(830 \mathrm{~g} \mathrm{~kg}^{-1}\right.$ 
171 of a cereal mix meals; $115 \mathrm{~g} \mathrm{~kg}^{-1}$ of a soybean meal; $50 \mathrm{~g} \mathrm{~kg}^{-1}$ of a sunflower meal; and $5 \mathrm{~g} \mathrm{~kg}^{-1} \mathrm{of} \mathrm{a}$ 172 mineral/vitamin supplement) without addition of any ADSs. The recovery values were estimated by spiking eight blank samples (25 g each) with $0.5 \mathrm{ml}$ of an $\mathrm{AFB}_{1}$ standard solution $\left(250 \mu \mathrm{g} \mathrm{l}^{-1}\right.$ dissolved in methanol) in order to obtain a concentration of $5 \mu \mathrm{g} \mathrm{kg}^{-1}$. After addition of the spiking solution, the organic solvent was evaporated at room temperature $\left(22^{\circ} \mathrm{C}\right)$ under a ventilated hood for 2 hours. The spiked samples were then analysed according to the two extraction procedures $(\mathrm{MeOH}$ and $\mathrm{AC}$, four replicates each) as described above. Four replicates of a certified reference material (ground corn, RBiopharm Rhône LTD) were also analysed.

\section{Statistical analyses}

The $\mathrm{AFB}_{1}$ contents in feedstuffs without ADSs were tested for homogeneity using the one-way analysis of variance procedure of $\mathrm{SAS}^{\circledR}$ (version 9.1, SAS Institute Inc., Cary, NC).

The $\mathrm{AFB}_{1}$ contents of the feedstuffs supplemented with ADSs were evaluated in a completely randomized design using the general linear model procedure of SAS $^{\circledR}$. A $2 \times 2 \times 9$ factorial arrangement for each AF contamination level (HC and LC) was used and fixed effects in the model included extraction procedure (Method; 2 levels), inclusion doses (Dose; 2 levels), ADSs (ADS; 9 levels) and associated first order and second order interactions. Dunnett's test was used for comparing treatments with the appropriate control (Lowry, 1992). Significance was declared at $P<0.05$.

\section{Results and discussion}

The average recovery values were $96.6 \pm 1.8 \%$ and $97.8 \pm 2.1 \%$ for $\mathrm{MeOH}$ and $\mathrm{AC}$ extraction procedures, respectively. The declared $\mathrm{AFB}_{1}$ contamination of the certified reference material was $4.1 \pm 1.0 \mu \mathrm{g} \mathrm{kg}^{-1}$; the results obtained were $4.2 \pm 0.2$ and $4.3 \pm 0.1 \mu \mathrm{g} \mathrm{kg}^{-1}$ using the $\mathrm{MeOH}$ and $\mathrm{AC}$ procedures, respectively. The limit of detection (LOD, signal-to-noise ratio of 3:1) and of 
quantification (LOQ, signal-to-noise ratio of 10:1) were respectively 0.02 and $0.05 \mu \mathrm{g} \mathrm{kg}^{-1}$.

No statistical differences were found in $\mathrm{AFB}_{1}$ levels of feedstuffs non containing ADSs, when extracted with $\mathrm{AC}$ or $\mathrm{MeOH}$, even if numerically higher values were obtained with $\mathrm{AC}$. The $F$-test at the $95 \%$ confidence level demonstrated that the sub-sample variance was not different from the analytical variance $\left(F_{\text {calc }}=0.479\right.$ and $F_{\text {calc }}=0.358$ versus $F_{\text {crit }}=3.500$, respectively for $\mathrm{HC}$ and LC), thus demonstrating good homogeneity of the prepared feeds (table 1).

Considering the composition of commercial clays (table 2 ), Novasil ${ }^{\mathrm{TM}}$ plus can be classified as a calcium montmorillonite (Pimpukdee et al., 2004; Bailey et al., 2006; Afriyie-Gyawu et al., 2008), a mineral clay that represents the main constituent of bentonite clays (Diaz and Smith, 2005). Atox ${ }^{\circledR}$, which is characterized by a high $\mathrm{Mg}$ level $(14.8 \pm 0.39 \%)$, can be classified as a magnesium bentonite, in agreement with the manufacturer's specifications; Myco AD AZ exhibited the highest carbon and the lowest ash level (41.0 and 75\%, respectively) among clays.

The statistical analysis showed a dose-dependent effect $(P<0.01)$ of ADSs inclusion on $\mathrm{AFB}_{1}$ recoveries, that were lower when the higher ADS dose $\left(20 \mathrm{~g} \mathrm{~kg}^{-1}\right)$ was included in the $\mathrm{HC}$ and LC feedstuffs (tables 3 and 4).

In particular, in $\mathrm{HC}$ feedstuff integrated with ADSs and extracted using the AC solvent, the average recovery was $75.0 \%$, while a very low $\mathrm{AFB}_{1}$ recovery $(12.0 \%)$ was obtained when the $\mathrm{MeOH}$ solvent was used. A similar trend, but higher $\mathrm{AFB}_{1}$ recoveries, was observed for the LC feedstuffs $(84.0$ and 22.8\% using $\mathrm{AC}$ and $\mathrm{MeOH}$, respectively). Therefore, the $\mathrm{AFB}_{1}$ extraction capacity of $\mathrm{MeOH}$ in feedstuffs containing ADSs resulted significantly lower $(P<0.001)$ with respect to AC: the $\mathrm{MeOH}$ method in presence of ADSs showed figures that are far from performance requirements for $\mathrm{AF}$ methods fixed in the EC Regulation 401/06 (recoveries of 70-110\% and 80-110\% in the range 1-10 and $>10 \mu \mathrm{g} \mathrm{kg}^{-1}$, respectively). Besides, when the $\mathrm{MeOH}$ extraction method was applied to HC feedstuffs integrated with $\mathrm{ADSs}$, the $\mathrm{AFB}_{1}$ concentrations resulted lower $(P<0.001)$ than the control value $(13.8$ 
$219 \mu \mathrm{g} \mathrm{kg}^{-1}$ ) for all the samples (table 3) and under the EU limit of $5 \mu \mathrm{g} \mathrm{kg}^{-1}$ (EC, 2003). On the contrary, 220 when $\mathrm{AC}$ was used the observed $\mathrm{AFB}_{1}$ concentrations exceeded this limit, with values ranging from 5.7 7

feedstuffs (table 4), with $\mathrm{AFB}_{1}$ concentrations exceeding the EU limit only when the analyses were performed using the AC solvent (with the exception of activated carbon).

In particular when the activated carbon was added to the feedstuffs the $\mathrm{AFB}_{1}$ content measured using the AC method differed $(P<0.001)$ from control values $\left(15.3\right.$ and $7.6 \mu \mathrm{g} \mathrm{kg}^{-1}$, respectively for $\mathrm{HC}$ and LC feeds) in all the experimental conditions (Tables 3 and 4). In presence of activated carbon, the $\mathrm{AFB}_{1}$ recoveries measured with $\mathrm{AC}$ at 10 and $20 \mathrm{~g} \mathrm{~kg}^{-1}$ were respectively $52 \%$ and $37 \%$ in the $\mathrm{HC} ; 55$ $\%$ and $39 \%$ in the LC feeds,. This can be due to a high affinity of the activated carbons versus the $\mathrm{AFB}_{1}$ molecule (Lemke et al., 2001; Vekiru et al., 2007) that could cause a reduction of extraction capacity of the AC mixture. In agreement with our data, Galvano et al. (1996) reported a similar reduction (from $41 \%$ to $74 \%$ ) of analytical content of $\mathrm{AFB}_{1}$ in a pelleted feed containing activated carbons.

Also when the sodium bentonite was added to contaminated feeds, lower $(P<0.05) \mathrm{AFB}_{1}$ concentrations with respect to controls were measured both in $\mathrm{HC}\left(20 \mathrm{~g} \mathrm{~kg}^{-1}\right.$ dose) and LC (10 and $20 \mathrm{~g}$ kg-1 doses) feedstuffs. However, the $\mathrm{AFB}_{1}$ recoveries were higher than those obtained for activated carbon, ranging from $63 \%$ to $76 \%$.

The data obtained in this experiment indicate that a routine use of the $\mathrm{MeOH}$ solvent for $\mathrm{AFB}_{1}$ analysis of unknown feedstuffs, can produce misleading results if they contain an ADS. Consequently, when an ADS is included in a contaminated feed, the analytical result for $\mathrm{AFB}_{1}$ could comply with or largely exceed the EU limit in feedstuffs for dairy animals (EU, 2003) according to whether it was obtained using $\mathrm{MeOH}$ or $\mathrm{AC}$ as extracting solvent, respectively. In any case, also AC did not result fully adequate for $\mathrm{AFB}_{1}$ quantification in experimental feeds containing two types of ADS (i.e., sodium 
bentonite and activated carbon). This fact suggests that other solvent mixtures should be evaluated to improve $\mathrm{AFB}_{1}$ extraction from feeds containing ADSs.

\section{Conclusions}

Erroneous data regarding the true $\mathrm{AFB}_{1}$ contamination level of a feedstuff may lead to incorrect managerial decisions in dairy farms and consequently to higher than expected $\mathrm{AFM}_{1}$ levels in milk. In fact, the $\mathrm{AFM}_{1}$ level in bulk milk $\left(\mu \mathrm{g} \mathrm{kg}^{-1}\right)$ depends on the quantity of $\mathrm{AFB}_{1}$ ingested $(\mu \mathrm{g}$ per cow per day). According to Veldman et al. (1992a), this relationship can be described by the following equation:

$$
\mathrm{AFM}_{1}\left(\mu \mathrm{g} \mathrm{kg}^{-1} \text { of milk }\right)=(1.19 * x+1.9) / 1000
$$

where $x$ is the $\mathrm{AFB}_{1}(\mu \mathrm{g})$ ingested daily by each cow in the herd.

According to our study, if $10 \mathrm{~kg}$ of the $\mathrm{HC}$ feedstuff is daily administered to cows, considering the $\mathrm{AFB}_{1}$ result obtained by $\mathrm{AC}$ extraction $\left(15.33 \pm 1.18 \mu \mathrm{g} \mathrm{kg}^{-1}\right), 153.3 \mu \mathrm{g}$ per cow per day can be calculated and the predicted $\mathrm{AFM}_{1}$ bulk milk concentration should be $0.184 \mu \mathrm{g} \mathrm{kg}^{-1}$. Otherwise, if 10 $\mathrm{kg}$ of the HC feedstuff containing $10 \mathrm{~g} \mathrm{~kg}^{-1}$ of an ADS is given to cows, the $\mathrm{AFB}_{1}$ level in the feed will be 12.4 or $2.3 \mu \mathrm{g} \mathrm{kg}^{-1}$ (mean values excluding the activated carbon thesis) according to whether the AC or $\mathrm{MeOH}$ solvent had been adopted, respectively. Consequently, a daily $\mathrm{AFB}_{1}$ consumption of 123.7 or $23.3 \mu \mathrm{g}$ per cow per day can be calculated, and a milk contamination of 0.149 or $0.030 \mu \mathrm{g} \mathrm{kg}^{-1}$ of $\mathrm{AFM}_{1}$ can be predicted. The latter value, calculated on the basis of the $\mathrm{MeOH}$ result, is well below the limit of $0.050 \mu \mathrm{g} \mathrm{kg}^{-1}$ set by the $\mathrm{EU}$ (EU, 2006), but the real situation is quite different, as reported in our previous work (Masoero et al., 2009). In conclusion, it is clear that the ascertainment of the real $\mathrm{AFB}_{1}$ concentration of feedstuffs containing $\mathrm{ADS}$ is essential to avoid putting dairy farmers at risk of unknowingly producing contaminated milk, which will have to be discarded. 


\section{Acknowledgments}

This research was supported by the AFLARID project of Ministero delle Politiche Agricole, Alimentari e Forestali (MiPAAF - Italy).

\section{References}

Afriyie-Gyawu E, Wang Z, Ankrah NA, Xu L, Johnson NM, Tang L, Guan H, Huebner HJ, Jolly PE, Ellis WO, Taylor R, Brattin B, Ofori-Adjei D, Williams JH, Wang JS, Phillips TD. 2008. NovaSil clay does not affect the concentrations of vitamins $\mathrm{A}$ and $\mathrm{E}$ and nutrient minerals in serum samples from Ghanaians at high risk for aflatoxicosis. Food Additives and Contaminats 7: 872-884.

Aldao MAJ, Carpinella MC, Corelli M, Herrero GG. 1995. Competitive ELISA for quantifying small amounts of aflatoxin B1. Food and Agricultural Immunology 7:307-314.

AOAC. 1995. Preparation of standards for mycotoxins. In: Helrich KC, editor. Official methods of Analysis of the AOAC International, vol.2, AOAC International, Arlington, USA. p. 3 (Method 970.44).

AOAC. 2006. Aflatoxin $B_{1}$ in cattle feed. In: Horwitz W, editor. Official methods of Analysis of the AOAC International, $18^{\text {th }}$ Edn, vol. I, AOAC International, Maryland, USA. Chapter 49, p. 38 (Method 2003.02).

Arranz I, Sizoo E, van Egmond H, Kroeger K, Legarda TM, Burdaspal P, Reif K, Stroka J. 2006. Determination of aflatoxin B1 in medical herbs: interlaboratory study. Journal of AOAC International 89:595-605.

Bailey CA, Lamiter GW, Barr AC, Wigle WL, Haq AU, Balthrop JE, Kubena LF. 2006. Efficacy of 
montmorillonite clay (NovaSil PLUS) for protecting full-term broilers from aflatoxicosis. Journal of Applied Poultry Research 15:198-206.

Berg T. 2003. How to establish international limits for mycotoxins in food and feed? Food Control $14: 219-224$.

Bradburn N, Coker RD, Bluden G. 1995. A comparative study of solvent extraction efficiency and the performance of immunoaffinity and solid phase columns on the determination of aflatoxin $\mathrm{B}_{1}$. Food Chemistry 52:179-185.

Brera C, Debegnach F, Minardi V, Pannunzi E, De Santis B, Miraglia M. 2007. Immunoaffinity column cleanup with liquid chromatography for determination of aflatoxin B1 in corn samples: interlaboratory study. Journal of AOAC International 90:765-772.

Diaz DE, Hagler WMJ, Blackwelder JT, Eve JA, Hopkins BA, Anderson KL, Jones FT, Whitlow LW. 2004. Aflatoxin binders II: Reduction of aflatoxin M1 in milk by sequestering agents of cows consuming aflatoxin in feed. Mycopathologia 157:233-241.

Diaz DE, Smith, TK. 2005. Mycotoxin sequestering agents: practical tools for the neutralisation of mycotoxins. In: Diaz DE, editor. The Mycotoxin Blue Book. Nottingham University Press, Thrumpron, Nottingham. p. 323-339

European Commission. 2003. Commission Directive 2003/100/EC of 31 October 2003 amending Annex I to Directive 2002/32/EC of the European Parliament and of the Council on undesirable substances in animal feed (Text with EEA relevance). Official Journal of the European Union L285:33-37.

European Commission. 2006. Commission Regulation (EC) No 1881/2006 of 19 December 2006 http://mc.manuscriptcentral.com/tfac Email: fac@tandf.co.uk 
setting maximum levels for certain contaminants in foodstuffs (Text with EEA relevance). Official Journal of the European Union L364:5-24.

IARC (International Agency for Research on Cancer). 2002. World health organization international agency for research on cancer. Aflatoxins: B1, B2, G1, G2, M1. In: Some traditional erbal medicines, some mycotoxins, naphthalene and styrene. IARC monographs on the evaluation of carcinogenic risks to humans, Lyon, France, vol. 82. p. 171-175.

Jaynes WF, Zartman RE, Hudnall WH. 2007. Aflatoxin $B_{1}$ adsorption by clays from water and corn meal. Applied Clay Science 36:197-205.

Jouany JP. 2007. Methods for preventing, decontaminating and minimizing the toxicity of mycotoxins in feeds. Animal Feed Science and Technology 137:342-362.

Karaman M, Basmacioglu H, Ortatatli M, Oguz H. 2005. Evaluation of the detoxifying effect of yeast glucomannan on aflatoxicosis in broilers as assessed by gross examination and histopathology. British Poultry Science 46:394-400.

Lemke SL, Ottinger SE, Mayura K, Ake CL, Pimpukdee K, Wang N, Phillips TD. 2001. Development of a multi-tiered approach to the in vitro prescrenning of clay-based enterosorbents. Animal Feed Science and Technology 93:17-29. 
Lowry SR. 1992. Use and misuse of multiple comparisons in animal experiments. Journal of Animal Science 70:1971-1977.

Masoero F, Gallo A, Diaz D, Piva G, Moschini M. 2009. Effects of the procedure of inclusion of a sequestering agent in the total mixed ration on proportional aflatoxin $\mathrm{M}_{1}$ excretion into milk of lactating dairy cows. Animal Feed Science and Technology 150:34-45.

Masoero F, Gallo A, Moschini M, Piva G, Diaz D. 2007. Carryover of aflatoxin from feed to milk in dairy cows with low or high somatic cell counts. Animal 1:1344-1350.

Möller TE, Nyberg M. 2004. Efficiency of different extraction solvent mixtures used in analyses of aflatoxins from a certified peanut meal reference material. Food Additives and Contaminants 8:781-785.

Pettersson H, Bertilsson J, Wennberg O. 1989. Carry-over of aflatoxin from dairy cattle feed to milk. Healthy animals, safe foods, healthy man. World Association of Veterinary Food Hygienists, 10th Jubilee International Symposium, p. 97-102.

Phillips TD, Sarr AB, Clement BA, Kubena LF, Harvey RB. 1991. Prevention of aflatoxicosis in farm animals via selective chemisorption of aflatoxin. In: Bray GA, Ryan DH, editors. Mycotoxins, Cancer, and Health. Louisiana State University Press, Baton Rouge, Louisiana, USA. p. 223237.

Pimpukdee K, Kubena LF, Bailey CA, Huebner HJ, Afriyie-Gyawu E, Phillips TD. 2004. Aflatoxininduced toxicity and depletion of hepatic vitamin A in young broiler chicks: protection of chicks in presence of low levels of NovaSil PLUS in the diet. Poultry Science 83:737-744.

Ramos AJ, Hernandez E. 1996. In vitro aflatoxin adsorption by means of a montmorillonited silicate. A http://mc.manuscriptcentral.com/tfac Email: fac@tandf.co.uk 
study of adsorption isotherms. Animal Feed Science and Technology 62:263-269.

Reif K, Metzger W. 1995. Determination of aflatoxins in medical herbs and plant extracts. Journal of Chromatography A 692:131-136.

Roebuck BD, Maxuitenko YY. 1994. Biochemical mechanism and biological implications of the toxicity of aflatoxins as related to aflatoxin carcinogenesis. In: Eaton DL, Groopman JD, editors. The Toxicology of Aflatoxins: Human Health, Veterinary, and Agricultural Significance. Academic Press Inc., San Diego, California, USA. p. 27-43.

Sànchez-Ramos S., Doménech-Carbò A., Gimeno-Andelantado J.V., Peris-Vicente J. 2008. Analytical and mineralogical studies of ore and impurities from a chromite mineral using X-ray analysis, electrochemical and microscopy techniques. Talanta 74:1592-1597.

SAS. Statistical Analysis System Propietary Software (release 8.2), 2001. SAS Institute Inc., Cary, NC.

Scheidegger KA, Payne GA. 2003. Unlocking the secrets behind secondary metabolism: a review of Aspergillus flavus from pathogenicity to functional genomics. Journal of Toxicology: Toxin Reviews 22:423-459.

Senyuva HZ, Gilbert J. 2005. Immunoaffinity column cleanup with liquid chromatography using postcolumn bromination for determination of aflatoxins in hazelnut paste: interlaboratory study. Journal of AOAC International 88:526-535.

Sharma M, Márquez C. 2001. Determination of aflatoxins in domestic pet foods (dog and cat) using immunoaffinity column and HPLC. Animal Feed Science and Technology 93:109-104.

Stroka J, Petz M, Joerissen U, Anklam E. 1999. Investigation of various extractants for the analysis of aflatoxin $\mathrm{B}_{1}$ in different food and feed matrices. Food Additives and Contaminants 16:331-338. 
1

2
Stroka J, von Holst C, Anklam E, Reutter M. 2003. Immunoaffinity column cleanup with liquid chromatography using post-column bromination for determination of aflatoxin B1 in cattle feed: collaborative study. Journal of AOAC International 86:1179-1186.

Trucksess MW, Wood EG. 1994. Recent methods of analysis for aflatoxins in foods and feeds. In: Eaton DL, Groopman JD, editors. The Toxicology of Aflatoxins: Human Health, Veterinary, and Agricultural Significance. Academic Press Inc., San Diego, California, USA. p. 409-431.

Van Eijkeren JCH, Bakker MI, Zeilmaker MJ. 2006. A simple steady-state model for carry-over of aflatoxins from feed to cow's milk. Food Additives and Contaminants 23:833-838.

Vekiru E, Fruhauf S, Sahin M, Ottner F, Schatzmayr G, Krska R. 2007. Investigation of various adsorbents for their ability to bind Aflatoxin $\mathrm{B}_{1}$. Mycotoxin Research 23: 27-33.

Veldman A, Meijs JAC, Borggreve GJ, Heeres-van-der-Tol JJ. 1992a. Carry-over of aflatoxin from cows' food to milk. Animal Production 55:163-168.

Veldman A. 1992b. Effect of sorbentia on carry-over of aflatoxin from cow feed to milk. Milchwissenschaft (abstract) 47:777-780.

Yiannikouris A, Bertin G, Jouany JP. 2005. Reducing mycotoxin impact: the science behind Mycosorb®. Nutritional biotechnology in the feed and food industries. In: Proceedings of Alltech’ s $21^{\text {st }}$ Annual Symposium, 22-25 May, Lexington, Kentucky, USA. p. 265-276. 
Table $1 . \mathrm{AFB}_{1}$ content $\left(\mu \mathrm{g} \mathrm{kg}^{-1}\right)$ of ingredients and feedstuffs using acetone:water $(\mathrm{AC} ; 85: 15 \mathrm{v} / \mathrm{v})$ and methanol:water $(\mathrm{MeOH} ; 80: 20 \mathrm{v} / \mathrm{v})$ extraction solvents and feedstuff composition $\left(\mathrm{g} \mathrm{kg}^{-1}\right)$.

\begin{tabular}{|c|c|c|c|c|c|}
\hline \multirow[t]{2}{*}{ Ingredients } & \multirow[b]{2}{*}{$\mathrm{n}^{\circ}$} & \multicolumn{2}{|c|}{$\mathrm{AFB}_{1}\left(\mu \mathrm{g} \mathrm{kg}^{-1}\right)$} & \multicolumn{2}{|c|}{ Feedstuff composition $\left(\mathrm{g} \mathrm{kg}^{-1}\right)$} \\
\hline & & $\mathrm{AC}$ & $\mathrm{MeOH}$ & $\begin{array}{l}\text { High contamination } \\
\qquad(\mathrm{HC})\end{array}$ & $\begin{array}{l}\text { Low contamination } \\
\text { (LC) }\end{array}$ \\
\hline High contaminated corn meal & 3 & $32.87 \pm 2.32$ & $29.46 \pm 3.01$ & 400 & 50 \\
\hline Low contaminated corn meal & 3 & $10.21 \pm 1.27$ & $8.78 \pm 1.57$ & 160 & 500 \\
\hline Wheat bran & 3 & $1.40 \pm 0.31$ & $1.36 \pm 0.22$ & 120 & 120 \\
\hline Barley meal & 3 & n.d. & n.d. & 150 & 160 \\
\hline Soybean meal & 3 & $1.11 \pm 0.23$ & $1.08 \pm 0.27$ & 115 & 115 \\
\hline Sunflower meal & 3 & n.d. & n.d. & 50 & 50 \\
\hline Trace-min./vit. Supplement ${ }^{\mathrm{a}}$ & 3 & n.d. & n.d. & 5 & 5 \\
\hline HC feedstuff & 9 & $15.33 \pm 1.18$ & $13.81 \pm 1.05$ & & \\
\hline LC feedstuff & 9 & $7.57 \pm 0.65$ & $7.02 \pm 0.63$ & & \\
\hline
\end{tabular}

n.d.: not detectable (under the LOD).

${ }^{\mathrm{a} C}$ Content per $100 \mathrm{~g}$ of trace min./vit. Supplement: $120000 \mathrm{IU}$ of vit. A; $9000 \mathrm{IU}$ of vit. $\mathrm{D}_{3} ; 90 \mathrm{mg}$ of vit. E; $3.6 \mathrm{mg}$ of Co; $19.2 \mathrm{mg}$ of I; $1.44 \mathrm{mg}$ of $\mathrm{Se} ; 600 \mathrm{mg}$ of Mn; $62.4 \mathrm{mg}$ of $\mathrm{Cu} ; 2240 \mathrm{mg}$ of $\mathrm{Zn} ; 1.92 \mathrm{mg}$ of Mo; $360 \mathrm{mg}$ of Fe. 
1 Table 2. Elementary composition and total ash content of the tested adsorbents.

\begin{tabular}{|c|c|c|c|c|c|c|c|c|c|c|}
\hline \multirow{2}{*}{ Adsorbents } & \multicolumn{9}{|c|}{ Elements (\%) } & \multirow{2}{*}{$\begin{array}{c}\text { Total Ash } \\
(\%)\end{array}$} \\
\hline & $\mathrm{C}$ & $\mathrm{O}$ & $\mathrm{Al}$ & $\mathrm{Si}$ & $\mathrm{Na}$ & $\mathrm{Mg}$ & $\mathrm{K}$ & $\mathrm{Ca}$ & $\mathrm{Fe}$ & \\
\hline Sodium bentonite & $3.3 \pm 0.61$ & $54.7 \pm 0.21$ & $9.7 \pm 0.13$ & $25.1 \pm 0.43$ & $1.4 \pm 0.03$ & $1.6 \pm 0.06$ & $0.2 \pm 0.01$ & $0.7 \pm 0.22$ & $2.7 \pm 0.09$ & $90.7 \pm 1.1$ \\
\hline Calcium bentonite & $9.7 \pm 0.17$ & $52.6 \pm 0.25$ & $6.0 \pm 0.09$ & $15.5 \pm 0.47$ & $0.6 \pm 0.10$ & $1.4 \pm 0.05$ & $1.6 \pm 0.19$ & $8.3 \pm 0.16$ & $3.8 \pm 0.21$ & $93.5 \pm 0.7$ \\
\hline Zeolite & $2.7 \pm 0.18$ & $56.0 \pm 0.18$ & $14.1 \pm 0.63$ & $14.6 \pm 1.05$ & $12.2 \pm 0.38$ & $0.1 \pm 0.02$ & $0.3 \pm 0.03$ & $0.1 \pm 0.02$ & $0.1 \pm 0.06$ & $99.8 \pm 0.1$ \\
\hline Kaolinite & $0.8 \pm 0.44$ & $57.0 \pm 1.07$ & $18.6 \pm 0.17$ & $21.0 \pm 0.35$ & n.d. & $0.2 \pm 0.04$ & $1.3 \pm 0.10$ & $0.1 \pm 0.05$ & $0.4 \pm 0.05$ & $88.8 \pm 1.2$ \\
\hline $\begin{array}{l}\text { Yeast cell wall- } \\
\text { based }\end{array}$ & $61.4 \pm 1.2$ & $34.8 \pm 0.04$ & n.d. & n.d. & $0.1 \pm 0.01$ & $0.2 \pm 0.04$ & $0.9 \pm 0.11$ & $1.4 \pm 0.76$ & n.d. & $8.1 \pm 0.3$ \\
\hline Activated Carbon & $89.6 \pm 0.84$ & $10.0 \pm 0.85$ & n.d. & $0.1 \pm 0.01$ & n.d. & n.d. & n.d. & $0.1 \pm 0.07$ & n.d. & $2.7 \pm 0.1$ \\
\hline Atox $^{\circledR}$ & $3.8 \pm 0.79$ & $53.7 \pm 0.58$ & $1.6 \pm 0.04$ & $21.8 \pm 0.47$ & $1.5 \pm 0.03$ & $14.8 \pm 0.39$ & $0.4 \pm 0.02$ & $0.6 \pm 0.25$ & $0.9 \pm 0.12$ & $94.6 \pm 0.9$ \\
\hline Myco AD AZ & $41.0 \pm 0.62$ & $34.6 \pm 0.38$ & $5.2 \pm 0.17$ & $14.4 \pm 0.57$ & $1.2 \pm 0.03$ & $0.9 \pm 0.02$ & $0.5 \pm 0.04$ & $0.6 \pm 0.07$ & $1.2 \pm 0.10$ & $75.1 \pm 0.1$ \\
\hline Novasil $^{\mathrm{TM}}$ plus & $4.2 \pm 1.02$ & $56.0 \pm 0.44$ & $8.5 \pm 0.35$ & $22.6 \pm 0.50$ & $0.2 \pm 0.06$ & $2.0 \pm 0.04$ & $0.6 \pm 0.30$ & $1.8 \pm 0.12$ & $3.5 \pm 0.13$ & $92.4 \pm 0.7$ \\
\hline
\end{tabular}

2 n.d.: not detectable (under the LOD) 
1 Table 3. $\mathrm{AFB}_{1}$ concentrations $\left(\mu \mathrm{g} \mathrm{kg}^{-1}\right)$ detected using acetone:water $(\mathrm{AC}, 85: 15 \mathrm{v} / \mathrm{v})$ and methanol:water $(\mathrm{MeOH}$,

$280: 20 \mathrm{v} / \mathrm{v})$ extraction solvents in HC feedstuff mixed with different adsorbents at two doses $\left(10\right.$ and $\left.20 \mathrm{~g} \mathrm{~kg}^{-1}\right)$. The

$3 \mathrm{AFB}_{1}$ concentrations in untreated $\mathrm{HC}$ (control) were $15.33 \pm 1.18$ and $13.81 \pm 1.05 \mu \mathrm{g} \mathrm{kg}^{-1}$ using $\mathrm{AC}$ and $\mathrm{MeOH}$,

4 respectively

\begin{tabular}{|c|c|c|c|c|}
\hline \multirow{3}{*}{ Adsorbent } & \multicolumn{4}{|c|}{ Dose } \\
\hline & \multicolumn{2}{|c|}{$10 \mathrm{~g} \mathrm{~kg}^{-1}$} & \multicolumn{2}{|c|}{$20 \mathrm{~g} \mathrm{~kg}^{-1}$} \\
\hline & $\mathrm{AC}$ & $\mathrm{MeOH}$ & $\mathrm{AC}$ & $\mathrm{MeOH}$ \\
\hline \multirow{3}{*}{ Sodium bentonite } & 13.01 & 0.96 & 9.93 & 0.45 \\
\hline & 9.73 & 0.75 & 8.53 & 0.52 \\
\hline & 12.44 & 0.82 & 10.76 & 0.66 \\
\hline mean & $11.72 \pm 1.75$ & $0.84 \pm 0.11$ 头隶 & $9.74 \pm 1.13 *$ & $0.54 \pm 0.11$ \\
\hline \multirow{3}{*}{ Calcium bentonite } & 12.70 & 1.69 & 10.30 & 1.44 \\
\hline & 12.48 & 1.59 & 11.67 & 0.40 \\
\hline & 12.50 & 1.67 & 12.53 & 1.02 \\
\hline mean & $12.56 \pm 0.12$ & $1.65 \pm 0.05$ 米隶米 & $11.50 \pm 1.13$ & $0.95 \pm 0.52$ 叛的 \\
\hline \multirow{3}{*}{ Zeolite } & 10.32 & 2.98 & 13.69 & 3.08 \\
\hline & 12.70 & 2.84 & 12.52 & 2.79 \\
\hline & 12.87 & 2.75 & 11.55 & 2.50 \\
\hline mean & $11.96 \pm 1.43$ & $2.86 \pm 0.12$ 头隶 & $12.59 \pm 1.07$ & $2.79 \pm 0.29$ \\
\hline \multirow{4}{*}{ Kaolinite } & 13.37 & 3.15 & 12.96 & 4.84 \\
\hline & 12.83 & 3.01 & 12.36 & 2.49 \\
\hline & 12.30 & 3.26 & 12.29 & 3.46 \\
\hline & $12.83 \pm 0.53$ & $3.14 \pm 0.13 * * \cdots$ & $12.54 \pm 0.37$ & $3.59 \pm 1.18$ \\
\hline \multirow{3}{*}{ Yeast cell wall-based } & 10.10 & 2.71 & 9.57 & 2.78 \\
\hline & 13.79 & 2.74 & 11.45 & 3.10 \\
\hline & 12.73 & 2.70 & 11.08 & 2.70 \\
\hline mean & $12.21 \pm 1.90$ & $2.71 \pm 0.02 * \cdots$ & $10.70 \pm 1.00$ & $2.86 \pm 0.21$ \\
\hline \multirow{3}{*}{ Activated Carbon } & 6.99 & 1.39 & 5.55 & 1.03 \\
\hline & 9.01 & 1.33 & 5.86 & 1.04 \\
\hline & 7.99 & 1.36 & 5.78 & 1.00 \\
\hline mean & $7.99 \pm 1,01^{* * * *}$ & $1.36 \pm 0.03 * * \cdots$ & $5.73 \pm 0.16 * * *$ & $1.03 \pm 0.02$ \\
\hline \multirow{3}{*}{ Atox $^{\circledR}$} & 14,15 & 1.42 & 12,91 & 0.83 \\
\hline & 15,07 & 1.05 & 14,02 & 0.76 \\
\hline & 10,25 & 1.56 & 10,37 & 0.33 \\
\hline mean & $13.16 \pm 2.56$ & 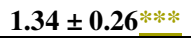 & $12.43 \pm 1.87$ & $0.64 \pm 0.27$ \\
\hline \multirow{3}{*}{ Myco AD AZ } & 12,97 & 4.41 & 11,19 & 0.50 \\
\hline & 14,09 & 4.22 & 9,90 & 0.59 \\
\hline & 10,66 & 4.05 & 13,81 & 0.55 \\
\hline mean & $12.58 \pm 1.75$ & $4.22 \pm 0.18$ 米冰 & $11.63 \pm 1.99$ & $0.55 \pm 0.04$ \\
\hline \multirow{4}{*}{ Novasil $^{\mathrm{TM}}$ plus } & 9.78 & 0.89 & 13.18 & 0.92 \\
\hline & 13.07 & 1.16 & 15.71 & 0.91 \\
\hline & 11.73 & 1.09 & 11.89 & 0.68 \\
\hline & $11.53 \pm 1.66$ & $1.05 \pm 0.14 * \cdots$ & $13.59 \pm 1.94$ & $0.84 \pm 0.13$ \\
\hline
\end{tabular}

$P$ of the model $<0.001 \quad$ S.E.M. ${ }^{\mathrm{a}} 0.6124$

Source of variation $(P$ value $)$

ADS $<0.001$ Dose $<0.01$ Method $<0.001$

ADS $x$ Dose $<0.05$ ADS x Method $<0.001$ Dose $x$ Method $=0.8503$

ADS $x$ Dose $x$ Method $=0.0702$

485 S.E.M.: standard error of the mean.

$496 \mid$ Superscripts signify means differ from respective controls: $* P<0.05, * * P<0.01$, $* * * P<0.001$.

Formatted: Font: $10 \mathrm{pt}$ Formatted: Font: $10 \mathrm{pt}$ Formatted: Font: Italic Formatted: Font: $10 \mathrm{pt}$ Formatted: Font: Italic Formatted: Font: $10 \mathrm{pt}$ Formatted: Font: Italic Formatted: Font: $10 \mathrm{pt}$ Formatted: Font: $10 \mathrm{pt}$ 
1

2

3
4

5 $3 \mathrm{AFB}_{1}$ concentrations in untreated $\mathrm{LC}$ (control) were $7.57 \pm 0.65$ and $7.02 \pm 0.63 \mu \mathrm{g} \mathrm{kg}^{-1}$ using $\mathrm{AC}$ and $\mathrm{MeOH}$, respectively.

1 Table 4. $\mathrm{AFB}_{1}$ concentrations $\left(\mu \mathrm{g} \mathrm{kg}^{-1}\right)$ detected using acetone:water $(\mathrm{AC}, 85: 15 \mathrm{v} / \mathrm{v})$ and methanol:water $(\mathrm{MeOH}$, $280: 20 \mathrm{v} / \mathrm{v})$ extraction solvents in LC feedstuff mixed with different adsorbents at two doses $\left(10\right.$ and $\left.20 \mathrm{~g} \mathrm{~kg}^{-1}\right)$. The

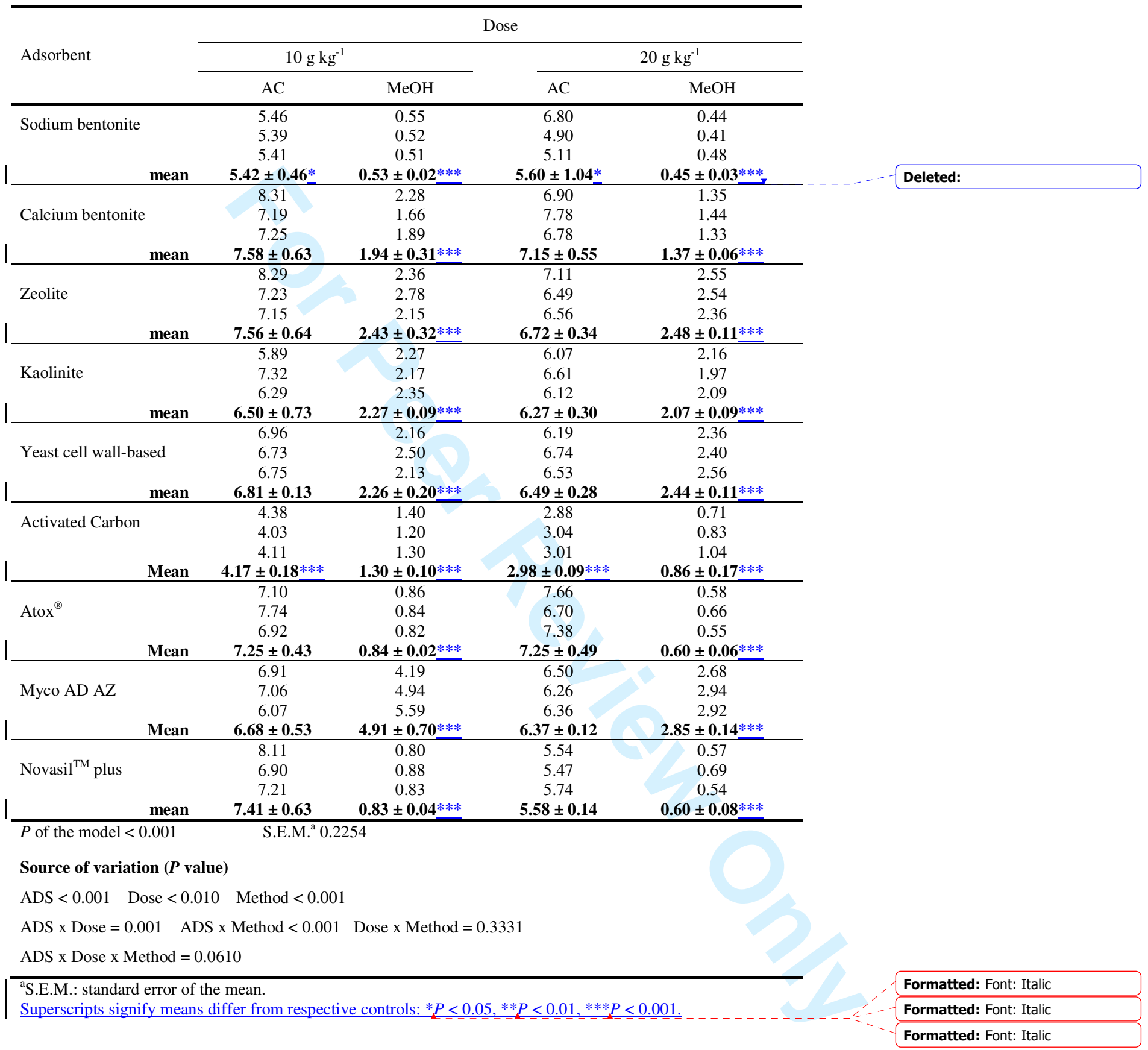

